\title{
Bist Ticaret Endeksinde Yer Alan Şirketlerin Springate Finansal Başarısızlık Modeli İle İncelenmesi
}

\author{
Eda DIZGIL $L^{1}$
}

\begin{abstract}
$\ddot{O} \mathbf{z}$
$\mathrm{Bu}$ çalışmanın amacı Borsa İstanbul'da Ticaret endeksinde hisseleri işlem gören şirketlerin Springate finansal başarısızlık modeli ile incelenmesidir. Bu amaçla BISTT Ticaret Endeksinde yer alan 18 şirketin 2012-2017 yıllarına ait yıllık finansal tablo verileri kullanılmıştır. Springate finansal başarısızlık modeli ile hesaplanan S skorları sonuçlarına göre şirketlerin ortalama $S$ değeri 0,99 olarak belirlenmiştir. $\mathrm{Bu}$ genel olarak bu şirketlerin iflas riskinin düşük olduğunu ve şirketlerin birçoğunun finansal açıdan başarılı olduğunu göstermektedir. Springate modelinde tahmin edilen iflas öngörüsünün ise gerçekleşmediği görülmüştür. Ancak bu durum şirketlerin iflas riskinin bulunmadığı anlamına gelmemektedir. Modelde yer alan birleşenler arasındaki ilişkilerin tespit edilmesi için korelasyon analizi yapılmıştır. Analiz sonucunda S skoru ile satışlar ile faiz ve vergi öncesi karlar arasında pozitif korelasyon ilişkisi tespit edilmiştir. Modelde kullanılan değiş̧kenlerin durağanlığını tespit etmek amacıyla birim kök testleri yapılmış ve değiş̧kenlerde birim kök tespit edilmiş bu durum serilerin birincil farkları alınarak düzeltilmiştir. Springate modelinde kullanılan değişkenlerin bu model sonucunda elde edilen $\mathrm{S}$ değeri üzerine etkisini tespit etmek amacıyla panel veri analizi yapılmıştır analiz sonucunda satışlar, faiz ve vergi öncesi karlar ve aktif toplamı ile $\mathrm{S}$ değeri arasında anlamlı bir ilişki olduğu tespit edilmiştir. $\mathrm{Bu}$ sonuca göre bu değişkenlerdeki artışı şirketlerin finansal başarı durumunu olumlu yönde etkileyeceği sonucuna varılmıştır.
\end{abstract}

Anahtar Kelimeler; Birim kök testi, Finansal başarısızlık, Springate Modeli, Panel veri analizi, Korelasyon analizi

\section{Investigation Of The Companies In The Bist Trade Index With Springed Financial Failure Model}

\begin{abstract}
The purpose of this study is to examine the companies that traded their shares in the Trade Index in Borsa Istanbul with Springate financial failure model. For this purpose, the annual financial statements of the 18 companies included in the BIST Trade Index for the years 2012-2017 are used. The average $S$ value of the companies was determined as 0.99 according to the results of $S$ scores calculated with Springate financial failure model. This in general shows that these companies have a low risk of bankruptcy and that many of the companies are financially successful. The predicted bankruptcy forecast in the Springate model was not realized. However, this does not mean that companies do not have the risk of bankruptcy. Correlation analysis was performed to determine the relationships between the components in the model. As a result of the analysis, the positive correlation between the $\mathrm{S}$ score and the pre-interest and pre-tax profits was determined. In order to determine the stability of the variables used in the model, unit root tests were performed and the unit root was determined in the variables and this situation was corrected by taking primary differences of the series. In order to determine the effect of the variables used in the Springate model on the $\mathrm{S}$ value obtained as a result of this model, the panel data analysis was performed. As a result of the analysis, it was determined that there was a significant relationship between the sales before interest, the profit before taxes and the total of assets. According to this result, it is concluded that the increase in these variables will positively affect the financial success of the companies.
\end{abstract}

Keywords; Unit root test, Financial failure, Springate Model, Panel data analysis, Correlation analysis

${ }^{1}$ Doktora Öğrencisi, Gaziantep Ünivertitesi, İşletme Ana Bilim Dalı, Muhasebe ve Finans Bölümü, dizgileda@gmail.com 


\section{Giriş}

Finansal başarısızlık küçük büyük tüm işletmelerin karşı karşıya kalabileceği bir durumdur. Başarısızlık farklı anlamları ifade den bir kavramdır. İşletmelerin sadece tek bir yan kuruluşunun başarısız olmasından bir işletmenin genelinin başarısız olmasına, kısa ve uzun vadeli yükümlülüklerini yerini getirememesinden, kredibilitesini kaybetmesine ve hatta iflasa sürüklenmesine kadar birçok durumu kapsar( Aydın 2010:490). İşletmelerde başarı kadar başarısızlıkta olağan bir durumdur olarak kabul edilmelidir.

İşletmeleri yaşayan canlı organizmalar olarak düşündüğümüzde yaşamın bir döneminde önlem alınmadığında işletmeleri yok olma noktasına getirebilecek bir durum ya da kötü bir hastalık olarak da ifade edilebilir başarısızlık. Bu hastalık ani bir biçimde kendini gösterebilir. Eğer organizmanın bağışıklığı yeterince güçlü değilse sistem dışarıdan destek almaya ihtiyaç duyabilir. Literatürde bu durum işletmelerin rehabilite edilmesi olarak ifade edilmektedir. İşletmeler önceden tahmin yöntemlerini kullanarak finansal başarısızlıklara karşı gerekli tedbirleri kendileri alabilir veya finansal olarak dışardan sağlanacak takviyelere ihtiyaç duyabilir. Kredi kuruluşları ile borçlarını ödeme hususunda esnek anlaşmalar yapabilir. Eğer borçlarını ödeyemezse kredi kuruluşları işletmenin mal varlığı için haciz kararı çıkartabilir. Bu durumda işletme mal varlığının veya yan kuruluşlarının bir kısmını bu kuruluşlara devrederek borçlarından kurtulabilir.

İşletmelerin hayatları boyunca karşılaştıkları bu sorunlara çözüm üretememeleri işletmelerin hayatlarını sürdürmelerine engel olmaktadır. Değişen şartlar ve küreselleşme ile birlikte karşılaşılan sorunlar da giderek karmaşık hale gelmekte ve içinden çıkılamaz bir hal almaktadır. Her tür başarısızlık karşısında üretilen çözümlerin yeterlilik derecesi son derece önemli hale gelmektedir. Bunun için işletmeler farklı model ve ölçütlerin geliştirilmesine ihtiyaç duymaktadır. Her tür beklenmedik soruna karşı gerekli tedbirlerin alınması işletme yönetiminin görevidir. Bu sorunlardan en önemlisi ise finansal yönetim sorunlarıdır. $\mathrm{Bu}$ sorunların önceden tespiti içinse finansal başarısızlıkların modelleri geliştirilmiştir. $\mathrm{Bu}$ çalışmada ise finansal başarısızlık modellerinden Springate Finansal başarısızlık modeli kullanılarak şirketlerin finansal başarı düzeyleri tespit edilmeye çalışılmıştır. Ayrıca buna ek olarak bir de ekonometrik analiz yapılımış Springate modelinde Hesaplanan $\mathrm{S}$ değerinin tespitinde kullanılan finansal tablo değişkenlerinin $\mathrm{S}$ değeri üzerine etkisi araştırılmıştır. Elde edilen sonuçlara ise yöntem ve örneklem kısmında yer verilmiştir. Sonuçlara ilişkin yorum ve değerlendirmelerde sonuçlar kısmında yer almaktadır.

\section{Kavramsal Çerçeve}

\section{Finansal Yükümlülükler Bakımından İşletmelerin Karşılaştığı Başarısızlık Türleri}

Finansal başarısızlık nakit akış yetersizliği sebebi ile finansal yükümlülüklerin zamanında yerine getirilmemesi olarak ifade edilebilir. İşletmelerin finansal yükümlülüklerini yerine getirememesi onların kredi değerliliğinin düşmesine sebep olurken bu durum işletmenin ticari 
itibarının da zedelenmesine neden olur. Bu açıdan işletmelerin karşılaştığı başarısızlık türlerini üç kategoride ele alabiliriz. Bunlar;

- Negatif ya da düşük kar seviyesi

- İşletmenin teknik açıdan likiditesini kaybetmesi

- İflas etmesi (öz sermeyenin negatife düşmesi)

\section{İşletmelerde Temel Başarısızlık Nedenleri}

İşletmelerde temel başarısızlık nedenleri iki grupta incelenmektedir. Bunlar işletmenin kendi iç yapısından kaynaklanan işletme içi nedenler diğeri ise ülke ekonomisinden kaynaklanan makro ekonomik nedenler olarak ifade edilmektedir. $\mathrm{Bu}$ nedenlerden bazıları aşağıda maddeler halinde sıralanmıştır. Bu maddelerde son üç sırada yer alan maddeler makro ekonomik nedenler diğerleri ise işletme içi nedenler olarak ifade edilebilir.

- Finansal planlama analizlerinin yeterli ve gerektiği şekilde yapılmaması

- Yeterli büyüme sağlanamaması veya büyüme hızının olduğundan fazla tespit edilmesi

- Alacak, stok ve satış yönetiminde etkinliğin sağlanmaması yani nakit yönetiminin etkin olmamas1

- Maliyetler aşırı derecede yüksek olmasına rağmen borçlanma düzeyinin de yüksek olması

- Öz sermaye yetersiz olmasına rağmen aşırı büyüme

- Etkin bir nakit yönetim politikasının izlenmesini sağlayacak teknikler kullanılmaması

- Faaliyetlerin yeterince çeşitlenememesi

- Piyasadaki rekabet ortamına uyum sağlanamaması

- Uluslararası rekabet imkânının bulunmaması

- Finansal krizler

\section{Finansal Krizler Karşısında İşletmelerin Alabilecekleri Önlemler}

Kriz başarısızlığa sebep olan önemli bir faktördür. Belirsizlik ve riskin derecesidir. İşletmeler açısından ise tehlike yaratan zarar veren bir durum olarak ifade edilmektedir (Aydın 2010:496). İşletmelerin finansal krizlerle yüz yüze kaldıklarında faydalanabilecekleri çeşitli yöntemler bulunmaktadır. Bu önlemler ve bunlara ilişkin açıklamalar aşağıda maddeler halinde sıralanmıştır;

- Stratejik Önlemler; SWOT analizi, Barter, sistemine dahil olmak( Barter, işletmelerin ihtiyaç duydukları malları para ödemeden atıl kapasite duran mal hizmetleri yine para almadan satarak ihtiyaçlarını finanse etmeleri şeklinde ifade edilir), orta ve uzun vadeli planlar yapmak, planlara uygun ürün gruplarına göre pazar hedeflerini belirlemek

- Masrafları Düşürücü önlemler; Bu önlemler genellikle likiditeyi artırmaya yöneliktir. Bunlardan bazıları; stok fazlası mevcut ise üretim harcamaları düşürülmelidir. Eğer işletmenin bir alanda rakiplerine karşı zayıf durumda olduğu düşünülüyorsa bu alandan çekilerek küçülme 
yoluna gidilebilir. İşletmede dışardan ürün ithalatı yapıyorsa döviz kurundaki dalgalanmalardan korunmak için yerli ürünlere yönelebilir. Çalışanların yıllık izinlerinin öne çekilmesi, fazla olan personelde azaltma yoluna gidilmesi, seyahat gideri otel masrafı iş gezilerinin azaltılması, personelin maaş prim vs. ücretlerinin dondurulması, duran varlık yatırımlarının azaltılması gibi uygulamalar yapilabilir.

- Nakit Girişlerini Hızlandırıcı Önlemler; İç pazarda oluşan kötü durumdan kurtulmak için dış pazara açılma, mümkün olan en kısa sürede tahsilatların yapılması, koşullar el verdiği ölçüde vadelerin tekrar düzenlenmesi, stok maliyetlerinin düşürülmesi amacıyla gerekli önlemlerin alınması gibi önlemler alınabilir.

\section{Başarısızlığın Önceden Tahmin Edilmesi}

Başarısızlık olasılığının önceden tahmin edilerek gerekli önlemler alınması yukarıda bahsedilen riskleri azaltma veya ortadan kaldırma açısından son derece önemlidir. $\mathrm{Bu}$ hususta işletmeler çeşitli faktörleri erken uyarı sistemi olarak kullanabilirler. Genelde uygulamalarda işletmelerin durumlarının kötüye gitmesinde aşağıda yer alan çeşitli göstergeler işletmeler açısından uyarı niteliği taşımaktadır. Dikkat edilmesi gereken bu göstergelerden bazıları şunlardır;

- Sürekli olarak borç edinme isteği

- Likidite sıkıntısından kurtulamama

- Satışlarda aşırı dalgalanmalar ve gerilemeler yaşanması

- Müşterilerin şikâyetlerinin artan bir ivme kazanması, müşteri kaybı yaşanması

- Sözleşme ve ödemelerde vadeye uyulmaması

- Yüksek maliyetle döviz üzerinden borçlanma

- İhracatta pazarın daralması, hammadde temininde dışa bağımlılığın artması

- Pazarlamada yaşanan sıkıntılar, ödemelerin vadesinde alınmaması

- Finansal tabloların gerçeğe uygun düzenlenmemesi

- İşletme gelirlerine kıyasla ortakların ölçüsüz isteklerindeki artışlar

\section{Başarısızlığın Ölçülmesi Amacıyla Kullanılan Yöntemler}

$\mathrm{Bu}$ yöntemlerde yapılan araştırmaların çoğu sağlam ve hasta işletmelerin tespit edilmesine dayanır. Burada hasta işletme finansal açıdan başarısız, sağlam işletme ise finansal açıdan başarılıdır. Bu yöntemlerden bazıları şunlardır;

- Altman Modeli; $\mathrm{Bu}$ model oran analizinin çok değişkenli olarak genişletilmesine dayanmaktadır. Çok aşamalı ve çok değişkenli bir ayrım analizidir. Bu analizde ağırlıklı olarak likidite, karlılık, etkinlik ve kaldıraç oranları kullanılmıştır. Böylece işletmenin kredi değerliliğini ve riskini ifade eden bir nokta değer hesaplamak istemiştir. 
- Beaver Modeli; $\mathrm{Bu}$ modelde de ayrım analizi yapılmıştır ancak diğer yöntemden farkları vardır. Beaver'e göre bir işletmenin sahip olduğu likit varlıkların bilhassa ekonomik dalgalanma dönemlerinde işletmeler açısından oldukça önemli işlevleri vardır. Dolayısıyla işletmelerin kredi değerliliğinin tespitinde likit değerler daha fazla önem arz etmektedir. Ve bu değerlerdeki artışa göre işletmenin kredi değerliliği artmaktadır. Bu yönteme yönelik literatür de yapılmış bir çok eleştirilerde bulunmaktadir.

- $\quad$ Springate Modeli; Bu çalışmamızda kullanılan modeldir. 1978 y1lında Gordon L.V Springate tarafından geliştirilmiştir. Altman modeli ile benzer özelliktedir. Çok aşamalı ve çok değişkenli bir modeldir. Bu modelin açıklaması daha sonraki bölümlerde detaylı olarak anlatılmıştır.

- Weibel Modeli; Weibel kötü ve iyi olan işletme çiftlerinin seçiminde kriter olarak iş kolu, işletme büyüklüğü, işletmenin yaşı, hukuki şekli, kuruluş yeri, konjonktür ve taşınmazların sahipliğinden faydalanarak Wilcoxon testi ile 42 oranı test etmiştir.

- $\quad$ Fulmer Modeli; John G. Fulmer tarafından geliştirilmiştir. Altman ve Springate modeli gibi çok değişkenli ayrım analizine dayanır. Onların modellerinden farklı olarak farklı oranlar kullanılmıştır.

- CA-Skoru Kanada Modeli; John Legault ve arkadaşları tarafından geliştirilmiştir. Çok değişkenli ayrım analizine dayanır. Analizde 30 farklı finansal oran kullanılmıştır.

Finansal oranlar kullanılarak yapılarak yapılan çalışmaların çoğunda işletmelerdeki olayların çoğunun önceden tahmin edilebilmesinin mümkün olduğu görülmüştür. Bu tür olayların önceden tahmin edilebilmesi ve bunlar için gereken önlemlerin zamanında alınması başarısızlıkların önlenmesinde kilit önem taşımaktadır. Ayrıca bu çalışmalarda birbirinden farklı oran demetinin kullanılması tek tek oranların değerlendirilmesinden daha sağlıklı ve doğru sonuçlar sağlamaktadır.

\section{Başarısızlığı Engelleyici Yaklaşımlar}

Çevrenin hızlı değişimi işletmeleri sürekli değişim ve yenileme faaliyeti içinde yer almaya zorlamaktadır. İşletmeler hayatlarını devam ettirebilmek için hem bu değişiklikleri önceden tahmin etmeli hem de dünyada küreselleşme ortamı ile birlikte ortaya çıkan rekabet ortamına ayak uydurabilmeyi başarabilmelidir. İşletmelerin geleceği ile ilgili kararların alınmasında etkisi olan birçok değişken mevcuttur. Zaman içerisinde bu değişkenlerin nitelikleri de sürekli olarak değişmektedir. Gelecek belirsizlik ve risklerle doludur. Ancak etkili bir planlama yapılması içinde geleceğin tahmin edilmemesi ve gelecekle ilgili ön görülerde bulunulmaması düşünülemez. Günümüz işletmeleri oldukça karmaşık olan bir sistem içerisinde faaliyet göstermektedir. Bu doğrulta işletmelerin üzerine düşen görev başarı için geleceği iyi tahmin etmek ve geleceğe ilişkin yeni strateji ve politikalar üretmektir. Bu strateji ve politikalar ne kadar iyi olursa işletmeler o ölçüde başarılı olacaktır. 


\section{Finansal Başarısızlık Durumunu İyileştirmede İzlenecek Yöntemler}

Başarısız olmanın ilk belirtisi yükümlülüklerin yerine getirilememesidir. Finansal durumu kötüye giden ve borçlarını ödeyemeyen işletmelerin bu durumdan kurtulmak için acil önlem alması ve bunları uygulamaya geçirmesi gerekir. Eğer başarısızlık üstesinden gelinebilecek seviyede ise aşağıda yer alan yöntemler duruma göre uygulanarak başarısızlığın önüne geçilebilir.

- CÇeşitli önlemler alarak sermaye yapısını sağlamlaştırmak

- $\quad$ Sermaye artırımını sağlamak için hisse senedi çıkarmak yada otofinansmana gitmek

- $\quad$ Etkili bir nakit yönetim politikası oluşturmak

- İşletmenin ihtiyacından fazla olan duran varlık ve gayrimenkulleri elden çıkartarak nakit girişi sağlamak

- $\quad$ Rekabette başarısız birimleri kapatarak küçülme yoluna gitme

- Borçlar öz kaynağa dönüştürülebilir.

- Son olarak da işletme faaliyetlerine son verme ve işletmeyi satma yoluna gidilir.

\section{Literatür Taraması}

Literatüre bakıldığında finansal başarısızlığın tahminine yönelik birçok farklı model kullanılarak yapılmış çalışmalar mevcuttur. Bu çalışmalardan bazıları şunlardır;

Beaver vd. (1966), 1954-1964 yıllarını kapsayan çalışmasında başarısız 79 işletmeyi belirlemiş ve bununla aynı faaliyet konulanda başarılı işletmeleri seçerek geliştirdiği modeli bu işletmeler üzerinde uygulamıştır. Yazara göre bir işletmenin likiditesi yüksek rezervlere sahip olmasının ekonomik dalgalanmaların yaşandığı dönemde çok büyük önem arz ettiğini vurgulamıştır. İşletmenin kredi değerliliğinin belirlenmesinde de bu likit rezervlerin önemini vurguladığı çalışmasında çeşitli finansal oranları kullanarak çok değişkenli ayrım analizi yapmıştır. Araştırmada yazar başarılı işletmelerin finansal oranlarının değerinin başarısız olan işletmelerden oldukça yüksek olduğunu belirlemiştir. Ayrıca başarısız işletmelerin oranlarının başarısızlık dönemlerine yaklaştıkça hızlı bir düşüş gösterdiği de yapılan analizler sonucu tespit edilmiştir.

Altman (1968), finansal açıdan başarı düzeyinin belirlemesine yönelik yaptığı çalışmasında çok değişkenli ayrım analizi yönteminden yararlanmıştır. Bu çalışmada firmanın likidite, karlılık, etkinlik ve kaldıraç oranlarını kullanmıştır. Yazar bu oranları birbiri ile ilişkilendirerek işletmelerin kredi değerliliğinin derecelerini ve risklerini tespit etmeye yönelik bir nokta değer belirlemeyi amaçlamıştır. Tesadüfi örnekleme yöntemini kullanarak 33 başarılı ve başarısız işletme seçmiştir. Ve modelde 22 çeşit finansal oran kullanmıştır. Bu model Z modeli olarak adlandırılmaktadır. Z modeline göre $\mathrm{z}<2,675$ ise işletme başarısız olarak değerlendirilmiştir. Modelin doğruluk derecesi ise \%95 olarak belirlenmiştir. 
Springate (1978), bu çalışmada çok değişkenli ayrım analizi yöntemini kullanmıştır. 4 temel oran üzerine başarılı ve başarısız işletmeleri tespit için bir model geliştirmiştir ve bir Z değeri hesaplamıştır. Z değeri 0,862 den küçük olan işlemeler başarısız kabul edilmiştir. Yazar modeli tesadüfi örnekleme yolu ile seçtiği 40 işletme üzerinde test etmiştir. Araştırma sonucunda modelin doğruluk derecesini \%92,5 olarak bulmuştur. Bothers (1979), Springate modelini aktif değeri toplamda 2,5 milyon doların üzerinde olan işletmeler üzerinde test etmiştir. Çalışma sonucunda modelin doğruluk derecesini \%88 olarak bulmuştur. Sands (1980), Springate modelini aktif büyüklüğü ortalama 63,4 milyon dolar üzerinde olan 24 işletme üzerine test etmiş̧tir. Modelin doğruluk derecesi \%83,3 olarak bulmuştur (Springate 1978'den akt. Aydın 2010:505-506).

Fulmer (1984), tarafindan yapılan bu çalışmada Altman ve Springate gibi çok değişkenli ayrım analizi kullanarak finansal başarısızlık tahmin etmeye çalışılmıştır. Fulmer 'in modelinde ortalama aktif büyüklüğü 455 milyon dolar olan 30 başarılı 30 başarısız işletme tespit etmiş ve bunların verilerini kullanmıştır. $H$ değerini veren bir denklem elde edilmiştir. H skoru sıfırdan küçük olan firmaların finansal problem ve iflas maliyetleri ile karşılaşma durumunun yüksek olduğunu tespit etmiştir. H skoru sıfırdan büyük olan firmaların ise finansal yönden başarılı olduklarını ifade etmiştir.

Aktaş vd. (2003), mali başarısızlık tahmininde yapay sinir ağları ve istatistiki modellerin karşılaştırılması ile ilgili çalışmalarında 1983 ve 1997 yılları arasında İMKB de işlem gören sanayi, ticaret ve hizmet işletmelerinin verilerini kullanışlardır. Veri setini oluştururken işletmelerin seçiminde çeşitli kriterler kullanarak 53 başarılı ve 53 başarısız olmak üzere toplam 106 işletmeden oluşan bir örneklem oluşturmuşlardır. Yöntem olarak ise çoklu regresyon analizi, diskriminint analizi, logit analizi ile yapay sinir ağları yöntemidir. Çalışma sonucunda yapay sinir ağlarının çoklu regresyon analizi yönteminden daha başarılı sonuçlar verdiğini tespit etmişlerdir.

Uzun (2005), finansal başarısızlığa neden olan faktörleri teorik olarak incelediği çalışmasında yazar bu konuda bilgi sahibi olmak isteyenlere finansal başarısızlık türleri, finansal başarısızlık nedenleri konusunda çok çeşitli bilgiler vermiştir.

Altaş ve Giray (2005), tekstil sektöründe finansal başarısızlığın çok değişkenli yöntemlerle tahmin edilmesine yönelik yaptıkları çalışmalarında İMKB ye kayıtlı tekstil sektöründe faaliyet gösterin şirketlerin 2001 yılı mali tablolarında yer alan verileri kullanarak 33 şirketin finansal oranlarını hesaplamışlardır. Daha sonra faktör ve lojistik regresyon yöntemini kullanarak verileri analiz etmişlerdir. Analiz sonucunda finansal başarısızlık tahmininde en etkili oranın likidite oranı olduğu bu oranının başarılı ve başarısız şirketler grubunda önemli farklılık gösterdiğini tespit etmişlerdir.

Türksoy (2007), konaklama işletmelerinde mali başarısızlığa yol açan nedenleri belirmek amacıyla yapılan çalışmada yazar daha önce bu konuda yapılan çalışmalarda elde edilen bulguların işletmelerin kontrolünde olup olmadığını teorik olarak araştırmıştır. 
Terzi (2011), finansal oranlar yardımıyla finansal başarısızlığın tahmin edilmesine çalışan yazar çalışmasında IMKB gıda endeksinde yer alan işletmelerin finansal başarısızlıklarını tespit emek amacıyla Altman Z skoru modelini kullanmıştır. Bunun için 19 farklı oran belirlemiş bu oranları tekli ve çoklu analizlere tabi tutarak bu oranların sayısını altıya düşürmüştür. Yapılan analiz sonucunda ise aktif karlılık ve borç öz kaynak oranının daha etkili olduğunu tespit etmiştir.

Yusuf vd. (2014), finansal performans ve finansal başarısızlık arasındaki ilişkiyi test etmesine yönelik yaptıkları çalışmada Malezya'da bulunan yerel bankaların verilerini kullanmışlardır. Çalışma sonucunda performans göstergesi olarak öz sermaye karlılık oranı dikkate alınırken finansal açıdan başarısızlık göstergesi olarak da "kredi kayıp karşılı̆̆ı / toplam borç oranını" kullanmışlardır. Sonuç olarak performans ile başarısızlık arasında anlamlı ve negatif yönlü bir ilişki tespit etmişlerdir.

Büyükarıkan ve Büyükarıkan (2014), BİST Bilişim sektöründe faaliyet gösteren işletmelerin 2008-2013 yıllarına ait verilerini kullanarak yaptı̆̆ çalışmada Altman ve Springate modelini kullanmıştır. Yine bu çalışmada yazarlar model birleşenleri arasındaki ilişkiye tespit içinde çeşitli istatistiksel analiz yöntemleri uygulamışlardır. Yapılan korelasyon analizi sonucunda ise her iki model arasında pozitif korelasyon olduğu tespit edilmiştir.

Ege vd. (2017), Fulmer modeline dayalı olarak finansal başarısızlık tahminine yönelik olarak yapılan bu çalışmada yazarlar BİST 100 endeksinde faaliyet gösteren imalat firmalarının 2011-2015 verilerini kullanmışlardır. Bu çalışmada da yine finansal başarısızlık ile finansal performans arasındaki ilişki tespit edilmeye çalışılmıştır. Finansal performans göstergesi olarak Tobin Q oranını kullanırken finansal başarısızlık göstergesi olarak da Fulmer H skoru modelini kullanmışlardır. Çalışma sonucunda ise bu oran ile $\mathrm{H}$ skoru arasında pozitif anlamlı bir ilişki tespit edilmiştir.

Ayan ve Değirmenci(2018), Finansal başarısızlık tahmini için bir lojistik regresyon modeli adlı çalışmalarında BİST Sınai Endeksinde faaliyet gösterin 143 şirketin 2013-2016 yıllarına ait verilerini kullanarak bir çalışma yapmışlardır. Analiz sonucunda 1,2 veya 3 yıl öncesinden finansal başarısızlık tahmin etmek için sadece finansal oranların yeterli olmadığı sonucunu elde etmişlerdir. Lojistik regresyon yönteminde ise finansal başarısızlığın bir yıl öncesinden tahmin edilebileceği sonucuna varmışlardır.

\section{Veri Seti Metodoloji}

Çalışmanın bu kısmında şirket başarısızlıklarında Sprinte modelinin kullanılması ve Springate modelinde kullanılan değişkenlerin S skoru üzerinde etkisini tespit etmek amacıyla çeşitli istatistiki testler yapılmıştır.

\section{Amaç ve Kapsam}

$\mathrm{Bu}$ çalışmanın amacı Borsa İstanbul Ticaret Endeksinde işlem gören şirketleri finansal başarısızlık tahmin yöntemlerinden Springate kullanarak finansal başarı düzeylerini incelemek ve 
Springate modelinde kullanılan değişkenlerin finansal başarısızlık tahmini için hesaplanan S değeri üzerine etkisini çeşitli ekonometrik analizler yardımıyla açıklamaktır. Bu amaçla BİST Ticaret Endeksinde yer alan şirketlerin 2012-2017 yıllarına ait verileri kullanılarak ilk olarak Springate modeli yardımıyla şirketlerin finansal açıdan başarılı olup olmadıkları araştırılmıştır. Daha sonra ise Springate modeline göre hesaplanan $\mathrm{S}$ değeri üzerinde bu değerin hesaplanmasında kullanılan oranlardan hangilerinin daha çok etkili olduğunu tespit etmek amacıyla gerekli ekonometrik analizler yapılmıştır. Analizde kullanılan verileriler Kamuyu Aydınlatma Platformundan elde edilmiştir. Bu çalışmanın örneklemini oluşturan Ticaret endeksinde yer alan firmalara ait bilgiler ise tablo 1 de yer almaktadır.

Tablo:1 2012-2018 Dönemi BisT Ticaret Endeksinde Yer Alan Şirketler

\begin{tabular}{|l|l|l|}
\hline 0 & BIST KODU & ŞiRKETLER \\
\hline & ADESE & Adese Alışveriş Merkezleri Ticaret A.Ş \\
\hline & BIMAS & BiM Birleşik Mağazalar A.Ş \\
\hline & BiziM & Bizim Toptan Satış Mağazaları A.Ş \\
\hline & CRFSA & Carrefoursa Carefour Sabancı Ticaret Merkezi A.Ş \\
\hline & DOAS & Doğuş Otomotiv Servis Ve Ticaret A.Ş \\
\hline & INTEM & İntema Innşaat Ve Tesisat Malzemeleri Yatırım Ve Pazarlama A.Ş \\
\hline & KIPA & KiPA Ticaret A.Ş \\
\hline 0 & MAVi & Mavi Giyim Sanayi Ve Ticaret A.Ş \\
\hline 1 & MIGROS & Metro Petrol Ve Tesisleri Sanayi Ticaret A.Ş Ticaret A.Ş \\
\hline 2 & MIPAZ & Milpa Ticari Ve Sınai Ürünler Paz. San. A.Ş \\
\hline 3 & PSDTC & Pergamon Status Dış Ticaret A.Ş \\
\hline 4 & SANKO & Sanko Pazarlama Ithalat Ve ihracat A.Ş \\
\hline 5 & SELÇUK & Selçuk Ecza Deposu Ticaret Ve Sanayi A.Ş \\
\hline 5 & SOKM & ŞOK Marketler Ticaret A.Ş \\
\hline
\end{tabular}

Kaynak: KAP( Kamuyu aydınlatma platformu)

\section{Yöntem ve Örneklem}

Araştırmanın örneklemi BİST Ticaret Endeksinde yer alan 18 şirketin 2012-2017 yıllarındaki verilerinden oluşmaktadır. Çalışmada kullanılan veriler bu şirketlerin denetimden geçmiş bilanço ve gelir tablolarından elde edilmiştir. Çalışmanın verileri Eviews paket programı ve excel programı kullanılarak ile analiz edilmiştir. Çalışmada ilk olarak şirketlerin başarılı olup olmadıklarını tespit etmek için Springate modeli uygulanmış ve elde edilen sonuçlara ilişkin yorumlar yapılmıştır. Daha sonra çalışmada kullanılan finansal tablo değişkenlerinin Springate S skoru üzerindeki etkisini test etmek amacıyla panel veri analizi uygulamasına gidilmiştir. Çalışmanın analiz kısmında panel veri 
analizini yapılması için gerekli temel varsayımları test etmek amacıyla çeşitli istatistiki testler yapılmıştır bu testlere ilişkin sonuçlar çalışmanın uygulama kısmında yer almaktadır. Endekste 18 şirket yer almaktadır ancak 5 şirketin verilerine tam olarak ulaşılamadığı için şirket sayısı 14'e düşmüştür.

\section{Uygulama ve Bulgular}

Çalışmada kullanılan Springate modeli S skoru değeri şu şekilde hesaplanmaktadır.

$$
S=1.03 X+3.07 Y+0.66 Z+0.4 Q
$$

\section{X: Çalışma sermayesi/ toplam varlıklar}

\section{Y: Faiz vergi öncesi kar/ toplam varlıklar}

\section{Z: Faiz vergi öncesi kar/ kısa vadeli borçlar \\ Q: satışlar/ toplam varlıklar}

$\mathrm{Bu}$ modele göre $\mathrm{S}$ değeri 0.862 den küçük olan firma başarısız kabul edilmiştir. BİST Ticaret Endeksinde yer alan şirketlerin S skoru sonuçları tablo:2 de yer almaktadır.

Tablo: 2 Ticaret Endeksi Şirketlerinin S skoru

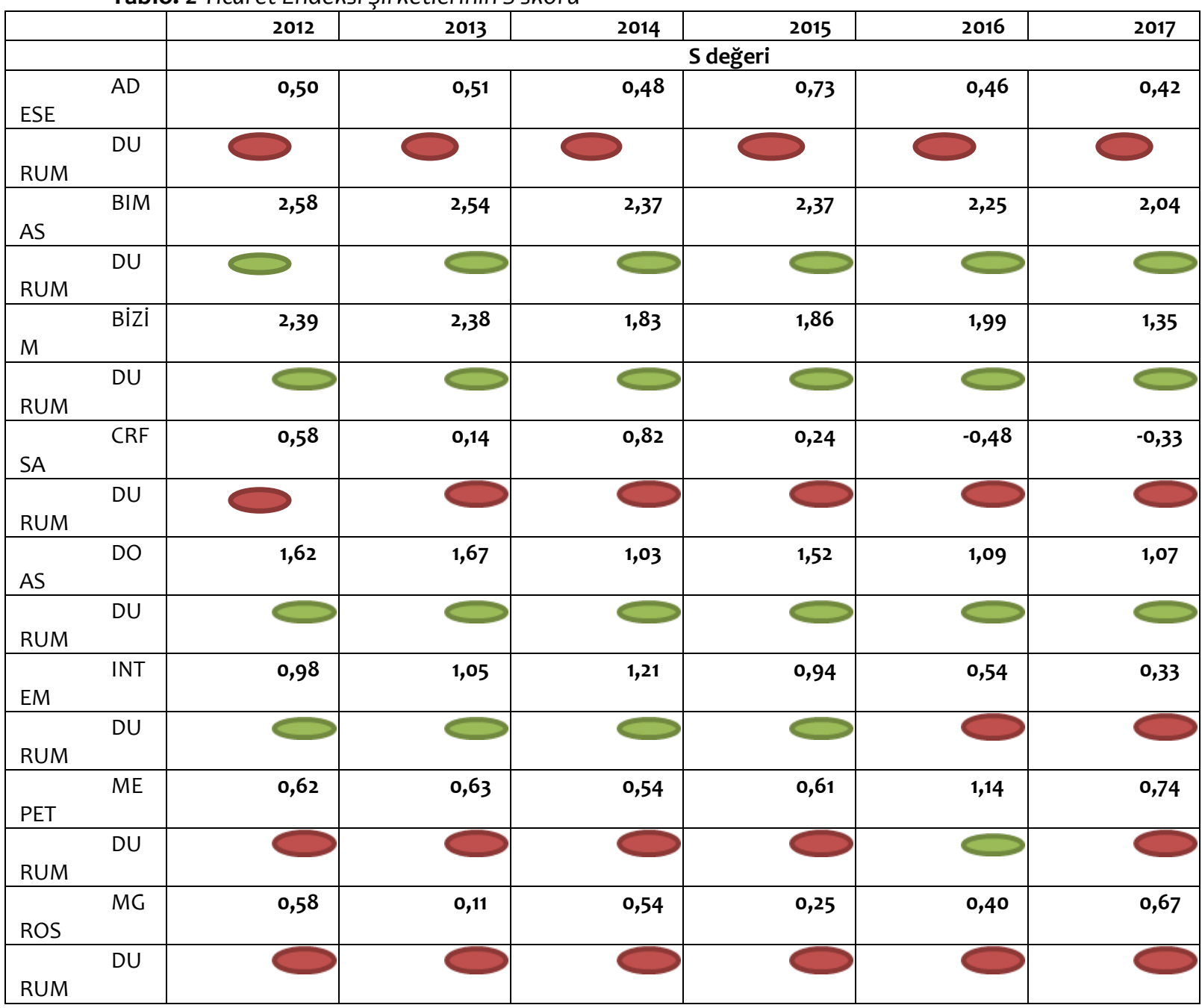




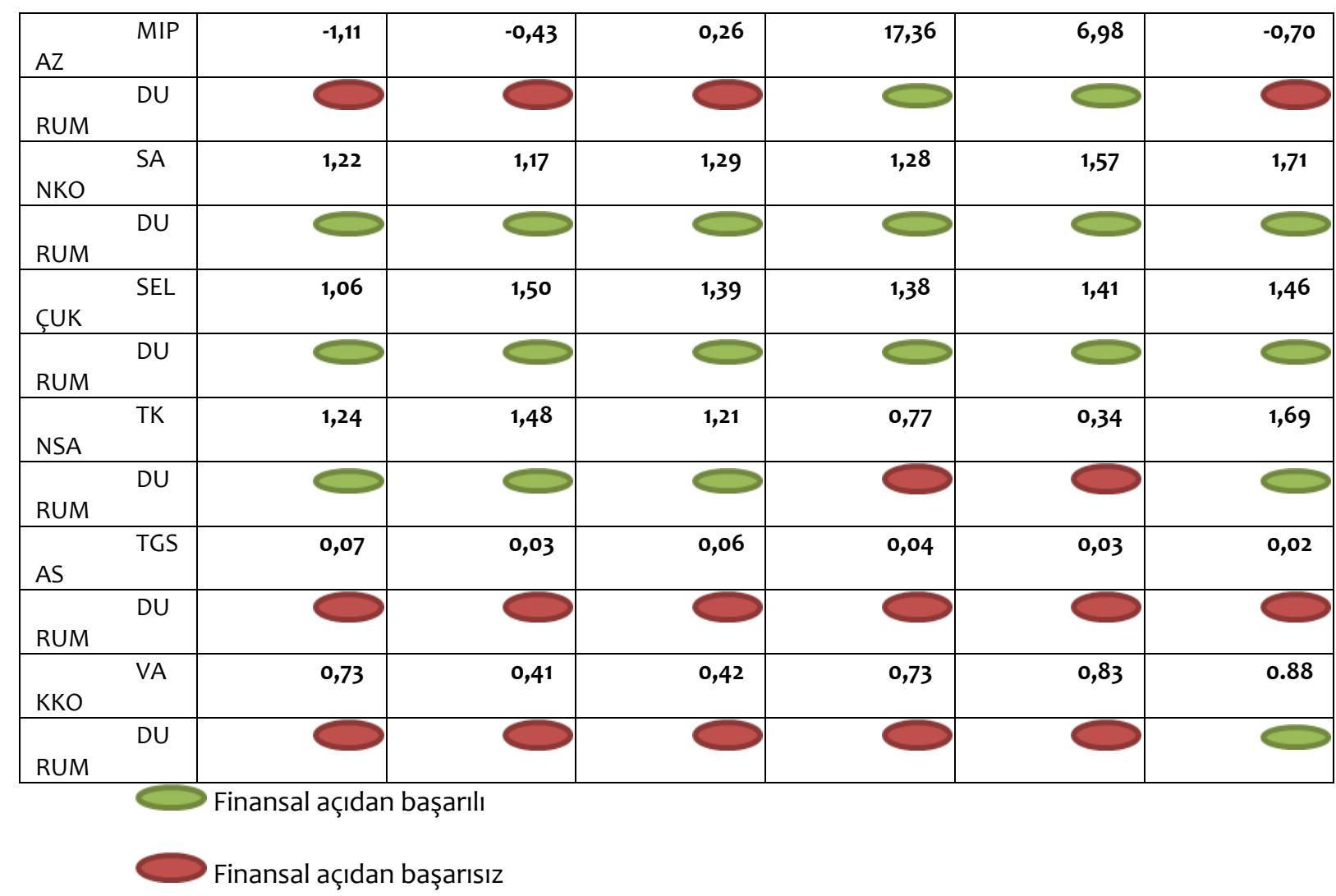

Yukarıdaki tabloda şirketlerin yıllar itibari ile Springate modeline göre S skoru sonuçları yer almaktadır. Bu sonuçlara göre S değeri 0,862 den küçük olan şirketler başarısız kabul edilmektedir. Burada başarısızlıktan kat edilen durum ise şirketlerin finansal yönetimde etkin olmadığı ve iflas risklerinin bulunduğu anlamına gelmektedir. Tabloyu incelediğimizde S değerine göre finansal açidan en başarılı şirketleri sıralayacak olursak BIMAS, BIZIM, DOAS, SANKO, SELÇUK gibi şirketler incelen bütün yıllarda en yüksek $S$ değerini elde etmiştir. Springate $S$ skoruna göre bu şirketlerin iflas riskleri düşük, finansal performanslarının ise yüksek olarak ifade edilebilir. Bunun dışında INTEM şirketinin S değeri 2012 den 2015 kadar iyi durumda iken 2015 de 20142014 yılına göre bir düşüş yaşanmış ve son iki yılda da bu düşüş devam etmiştir. Bunun sebebi olarak da s değerinin hesaplanmasında kullanılan finansal oranlardan işletme sermayesi oranda yaşanan düşüş kısa vadeli yabancı kaynaklardaki artış ve dönen varlıklardaki azalış ve karlardaki artış olarak ifade edebiliriz. TKNSA şirketinin ise ilk üç yıl S skoru şirketin finansal açıdan başarılı olduğunu gösterirken 20152016 yıllarında $\mathrm{S}$ skoru istenin düzeyin altına düşmüştür. $\mathrm{Bu}$ düşüşün sebebine baktığımızda $\mathrm{S}$ skorunun hesaplanmasında kullanılan değişkenlerden kısa vadeli yabancı kaynaklardaki artış buna karşı1ık dönen varlıkların bu değişken karşında daha az artması bunun sonucu olarak da işletme sermayesindeki azalış gösterilebilir. Bir diğer faktör ise şirketin bu yıllarda kardan zarara geçmesi olarak gösterilebilir. Daha sonra 2017 de şirket toparlanarak tekrar kar elde etmiş bu S skoruna olumlu etki etmiştir. 
S skoruna göre finansal açıdan en başarısız şirketler ise tablodan da görüleceği üzere her yıl istenen değerin altında bir değer elde eden ADESE, CARFUR, TGSAS, MEPET ve VAKKO olmuştur. Vakko sadece 2017 de S skorunun istenen seviyeye çıkartmıştır. MEPET de VAKKO ile aynı durumdadır bu şirkette sadece $2016 \mathrm{~S}$ skorunu istenen düzeye çıkarmıştır. MIPAZ şirketi de ilk üç yıl istenen S Skoru değerini elde edememiş 2015-2016 y1lları arasında zarardan kara geçerek S değerini artırmıştır. Ancak 2017 de tekrar Zarar ederek S değerini istenen seviyenin altına düşürmüştür.

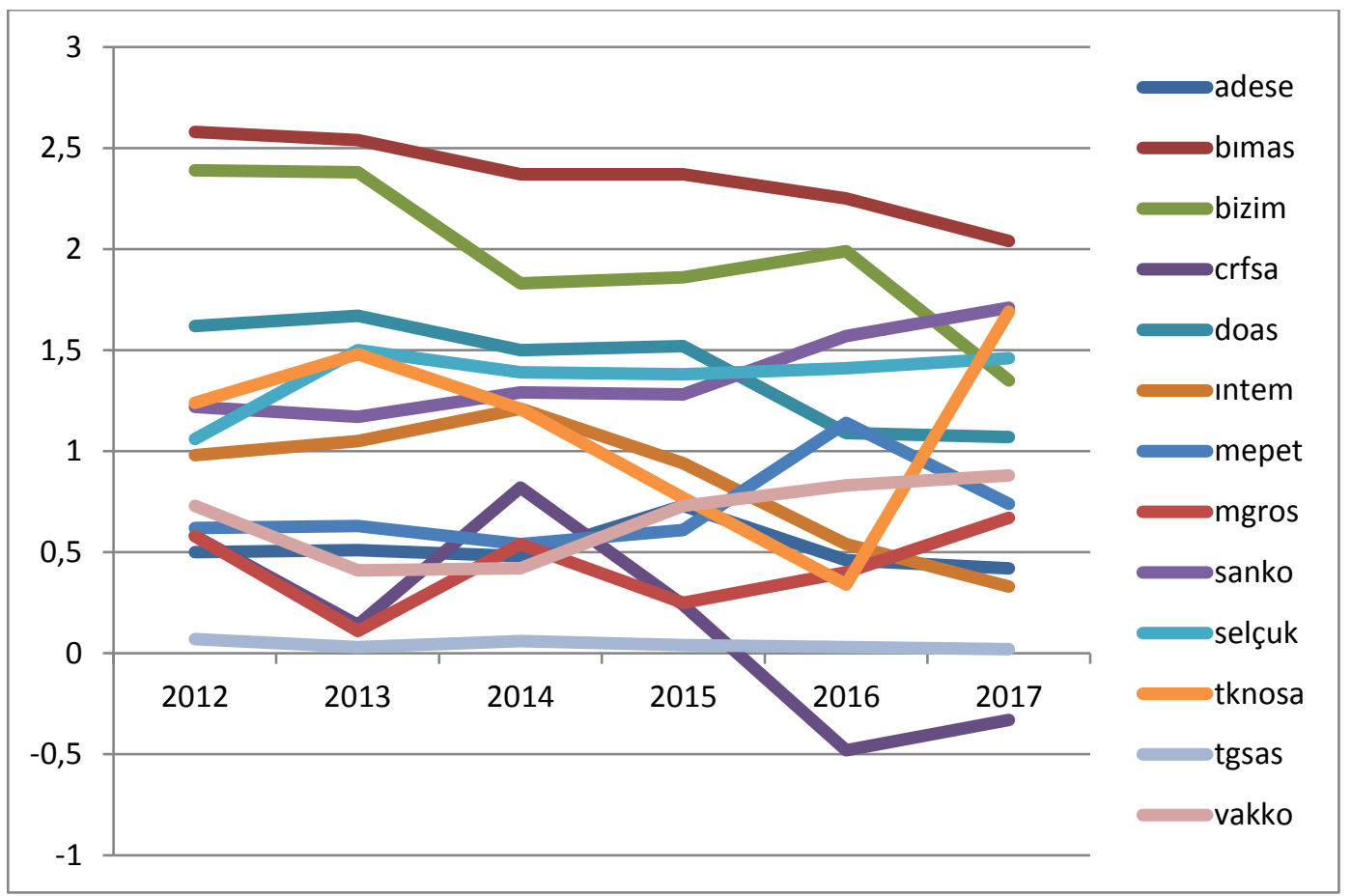

Şekil 1. Firmaların yıllara göre S değerleri

Yukarıdaki şekilde firmaların yıllar itibariyle S değerleri görülmektedir. Bu grafikte MIPAZ kodlu şirkete serinin değerini bozduğu için yer verilmemiştir. Grafikten görüleceği üzere S değeri en durağan olan şirketler TGSAS daha sonra SELÇUK, SANKO, VAKKO, BIMAS, DOAS olmuştur. En dalgalı S değerine sahip şirketler ise MEPET, CRFSA, TKNOSA, MIGROS olmuştur. S skoruna göre şekildeki grafikten görüleceği üzere finansal açıdan en başarılı şirketler BIMAS, BIZIM, DOAS ve SELÇUK şirketleri olmuştur. Springate modelinden hesaplanan S skoruna göre ise en başarısız şirketler ise CARFUR ve MIGROS olmuştur.

S değeri ile bu değerin hesaplanmasında kullanılan finansal tablo birleşenleri arasındaki korelasyon ilişkisi tablosu aşağıda verilmiştir. 
Tablo:3 Korelasyon Tablosu

\begin{tabular}{|c|c|c|c|c|c|c|c|}
\hline & $\begin{array}{l}\text { Aktif } \\
\text { toplamı }\end{array}$ & $\begin{array}{l}\text { Dönen } \\
\text { varlıklar }\end{array}$ & $\begin{array}{l}\text { Faiz vergi } \\
\text { öncesi kar }\end{array}$ & $\begin{array}{l}\text { İşletme } \\
\text { sermayesi }\end{array}$ & $\begin{array}{l}\text { Kısa vadeli } \\
\text { yabancı } \\
\text { kaynaklar }\end{array}$ & Satışlar & S değeri \\
\hline Aktif toplamı & 1.00 & 0.864560 & 0.447057 & 0.020818 & 0.952371 & 0.842538 & 0.052056 \\
\hline $\begin{array}{l}\text { Dönen } \\
\text { varlıklar }\end{array}$ & & 1.00 & 0.515739 & 0.266744 & 0.879029 & 0.782738 & 0.136676 \\
\hline $\begin{array}{l}\text { Faiz vergi } \\
\text { öncesi kar }\end{array}$ & & & 1.00 & 0.029286 & 0.441953 & 0.724833 & 0.621079 \\
\hline $\begin{array}{l}\text { İşletme } \\
\text { sermayesi }\end{array}$ & & & & 1.00 & 0.007538 & 0.005713 & 0.033555 \\
\hline $\begin{array}{l}\text { Kısa vadeli } \\
\text { yabancı } \\
\text { kaynaklar }\end{array}$ & & & & & 1.00 & 0.851638 & 0.023233 \\
\hline Satışlar & & & & & & 1.00 & 0.409365 \\
\hline S skoru & & & & & & & 1.00 \\
\hline
\end{tabular}

Korelasyon analizi iki yada daha fazla değişken arasında ilişki olup olmadığını tespit etmek amacıyla yapılan bir analizdir. Bu analiz sonucunda değişkenler arasındaki ilişkinin yönü ve büyüklüğü öğrenilebilmektedir. Korelasyon kat sayısı 0 ile 1 arasında bir değer almaktadır. Korelasyon değeri pozitif veya negatif olabilmektedir. Değerin pozitif olması iki değişken arasında pozitif bir ilişki olduğunu gösterirken negatif olması iki değişken arasında negatif bir ilişki olduğunu göstermektedir. Korelasyon kat sayıları aşağıda yer alan tabloya göre yorumlanabilir.

Tablo: 4 Korelasyon Sonuçlarının Anlamı

\begin{tabular}{|l|l|}
\hline Kat sayı & Yorumu \\
\hline Kat sayı $>0,2$ ise & Çok zayıf ilişki yada korelasyon yok demektir. \\
\hline $0.2-0,4$ arasında ise & Zayıf korelasyon \\
\hline $0.4-0,6$ arasında ise & Orta korelasyon \\
\hline 0,8 den büyük ise & Yüksek korelasyon vardır diyebiliriz \\
\hline
\end{tabular}

Tablo:3 de yer alan S değerinin hesaplanmasında kullanılan değişkenlerin birbirleri ile ve $\mathrm{S}$ değeri ile korelasyon ilişkilerini tek tek incelediğimizde aktif toplamı ile en yüksek pozitif korelasyon ilişkisi dönen varlıklar kısa vadeli yabancı kaynaklar ve satışlar arasında gerçekleşmiştir. Aktif toplamı ile $\mathrm{S}$ değeri arasında ise herhangi bir korelasyon ilişkisinin bulunmadığı tespit edilmiştir. Bunun anlamı aktif toplamındaki artış veya azalış S değerini etkilememektedir. Dönen varlıklarda ise en yüksek pozitif korelasyon ilişkisi kısa vadeli yabancı kaynaklar ve satış arasındadır. Yani kısa vadeli yabancı kaynaklar ve satı̧̧lardaki artış ya da azalış dönen varlıklarda da aynı yönde artış veya azalışa neden olmaktadır. Dönen varlıklar ile S değeri arasında da korelasyon ilişki tespit edilmemiştir. Faiz vergi öncesi karlar ile satışlar arasında pozitif korelasyon bulunmuştur yani satışlardaki artış veya azalış faiz ve vergi öncesi karlarda da artış veya azalışa neden olmaktadır. Faiz ve vergi öncesi karlar ile S değeri arasında pozitif korelasyon ilişkisi tespit edilmiştir. Bunun anlamı faiz ve vergi öncesi kardaki artış veya azalış $\mathrm{S}$ değerin de artış veya azalışa neden olmaktadır. Kısa vadeli yabancı kaynaklarla satışlar arasında da pozitif yönlü yüksek korelasyon tespit edilirken S değeri ile kısa vadeli 
yabancı kaynaklar arasında korelasyon ilişkisi bulunmamıştır. Satışlar ile S skoru arasında da düşük korelasyon ilişki bulunmuştur. Bu sonuçları kısaca özetleyecek olursak S skorunu üzerinde faiz vergi öncesi karlar ve satışların pozitif yönlü etkisi bulunmaktadır.

\section{Panel Veri Analizi Yönteminin Uygulanması}

$\mathrm{Bu}$ aşamada şirketlerin finansal açıdan başarı veya başarısızlık durumlarının öngörüsünde kullanılan Springate modelinden elde edilen S skorundaki değişkenlerin bu skoru üzerinde etkili olup olmadıklarını belirlemek amacıyla panel veri analizi yapılmıştır. Bu çalışmada panel veri analizi yönteminin seçilmesinin nedeni ise veri setinin hem yatay hem de dikey kesit olmasıdır. Panel veri analizi uygulamasına geçmeden ilk önce verilerin durağanlık sınamasını yapmak amacıyla Levin, Lin ve Chu(LLC), Genişletilmiş Dickey Fuller( ADF) birim kök testleri uygulanmıştır. Bu testlere ilişkin sonuçlar tablo 5 de yer almaktadır.

Tablo: 5 Birim Kök Testi Sonuçları

\begin{tabular}{|c|c|c|c|c|c|}
\hline \multirow[t]{2}{*}{ Değişkenler } & \multirow[t]{2}{*}{ Birim kök testi } & \multicolumn{2}{|c|}{ Seviye düzeyinde } & \multicolumn{2}{|l|}{ Birincil fark } \\
\hline & & $\begin{array}{l}\text { T } \\
\text { İstatistik }\end{array}$ & $\begin{array}{l}\text { Olasılık } \\
\text { değeri }\end{array}$ & T istatistik & $\begin{array}{l}\text { Olasılık } \\
\text { değeri }\end{array}$ \\
\hline LOG Aktif toplamı & LLC & 8.63217 & 1.000 & -2.47427 & $0.0067^{*}$ \\
\hline LOGDönen varlıklar & LLC & 8.52195 & 1.000 & -2.19476 & $0.0141 *$ \\
\hline LOGFaiz vergi öncesi kar & LLC & 2.63352 & 0.9958 & -10.6566 & $0.0000 *$ \\
\hline LOGişletme sermayesi & LLC & 6.51334 & 1.000 & -4.71336 & $0.0000 *$ \\
\hline $\begin{array}{l}\text { LOGKısa vadeli yabancı } \\
\text { kaynak }\end{array}$ & LLC & 15.6628 & 1.000 & -2.10258 & $0.0178^{*}$ \\
\hline LOGSatışlar & LLC & 13.6217 & 1.000 & -1.65699 & $0.0488 *$ \\
\hline LOGS değeri & LLC & -2.40089 & $0.0082 *$ & -11.6438 & $0.0000 *$ \\
\hline LOG Aktif Toplamı & ADF & 6.43666 & 1.000 & 39.8445 & $0.0404^{*}$ \\
\hline LOG Dönen Varlıklar & ADF & 5.21470 & 1.000 & 46.4603 & $0.0081 *$ \\
\hline LOGFaiz vergi öncesi kar & ADF & 8.11854 & 0.9997 & 100.173 & $0.0000 *$ \\
\hline LOGişsletme sermayesi & ADF & 6.85232 & 0.9999 & 72.8119 & $0.0000 *$ \\
\hline $\begin{array}{l}\text { LOGKısa vadeli yabancı } \\
\text { kaynak }\end{array}$ & ADF & 3.78276 & 1.000 & 51.9319 & $0.0018 *$ \\
\hline LOGSatışlar & ADF & 1.93997 & 1.000 & 40.2586 & $0.0368 *$ \\
\hline LOG S değeri & ADF & 37.6341 & 0.0655 & 85.5273 & $0.0000 *$ \\
\hline
\end{tabular}

*\%1, \%5,\%10 Anlamlılık düzeyini ifade etmektedir.

Yapılan birim kök testi sonucunda seriler ilk olarak seviye düzeyinde birim kök testlerine tabi tutulurken yapılan test sonucunda serilerin birim kök içirdiği yani durağan olmadığı normal dağılmadığı tespit edilmiştir. Bu şekilde panel veri analizi uygulamasına geçilemeyeceği için serilerin birincil farkları alınarak tekrar aynı testler yapılmıştır. Yapılan testler sonucunda serilerin birincil farklarının birim kök içermediği ve durağan olduğu tespit edilmiştir. Ayrıca değişkenlerin değerlerinin çok büyük olması analizde yüksek rakamlar çıkaracağı durumu da göz önünde bulundurularak değişkenlerin logaritmaları alınarak analize devam edilmiştir.

Çalışmada kullanılan değişkenlere ilişkin tanımlayışı istatistikler tablo:6 da yer almaktadır. 
Tablo:6 Tanımlayıc İstatistikler

\begin{tabular}{|l|l|l|l|l|l|l|}
\hline Değişken & Ortalama & Medyan & S. sapma & Max & Min & Jarque Bera \\
\hline LOG AT & 20.71048 & 20.45953 & 1.173 & 23.05567 & 18.54069 & $4.754134^{*}$ \\
\hline LOG DV & 20.18728 & 20.20921 & 1.221 & 22.23630 & 17.38206 & $1.722950^{*}$ \\
\hline LOG FVOK & 17.42231 & 17.29226 & 1.944 & 20.81480 & 13.81847 & $4.175675^{*}$ \\
\hline LOG IS & 18.26259 & 18.11078 & 1.808 & 23.29382 & 12.40589 & $0.959420^{*}$ \\
\hline LOGKVYK & 20.12449 & 20.24056 & 1.317 & 22.43094 & 16.80463 & $3.186446^{*}$ \\
\hline LOGSAT & 21.04737 & 21.55888 & 1.958 & 23.93328 & 1543617 & 18.81647 \\
\hline S DEĞERi & 0.990769 & 0.855000 & 0.718 & 2.580000 & -0.48000 & $2.901892^{*}$ \\
\hline
\end{tabular}

Tanımlayıcı istatistikler tablosunu incelediğimizde Springate S skoru 0.862 den küçük olan firmalar finansal açıdan başarısız kabul edilmektedir. Tanımlayıcı istatistikler tablosunu incelediğimizde $\mathrm{S}$ değeri ortalamasının 0.99 olduğunu görmekteyiz. $\mathrm{Bu}$ değer 0.862 değerinden yüksek bir değer olduğu için incelenen firmaların finansal açıdan başarılı olduklarını ifade edebiliriz. Tablodaki değişkenleri standart sapma açısından incelediğimizde faiz vergi öncesi kar ve satışlar dışında diğer değişkenlerde yıllar itibari ile önemli değişiklikler yaşanmadığını görmekteyiz. Serilerin hata terimlerinin normal dağılıp dağılmadığına ilişkin yorumları Jarque Bera testi ile yapmaktayız. Bu test sonuçlarını incelediğimizde serlerin hata terimlerinin bir değişken dışında normal dağıldığını görmekteyiz.

Tablo:6 da yer alan değişkenlerin kısaltmaları yer almaktadır. Bu kısalmaların açıklamaları aşağıda yer almaktadır;

- LOG AT: Aktif toplamının logaritması

- LOG DV: Dönen varlıkların logaritması

- LOG FVOK: Faiz veri öncesi karların logaritması

- LOG IS: İşletme sermayesinin logaritması

- LOG KVYK: Kısa vadeli yabancı kaynakların logaritması

- LOG SAT: Satışların logaritması

- S DEĞERİ: Springate Skoru

Panel veri analizinde üç yöntem vardır. Bunlar: havuzlanmış en küçük kareler yöntemi, sabit etkiler ve rassal etkiler yöntemidir. Bu yöntemlerden hangisinin kullanılacağını tespit etmek amacıyla çeşitli testler uygulanır. Çalışmada hangi testin kullanılacağını belirlemek amacıyla F Testi, BreuschPagan Langrange Çarpanı ve Hausman testi uygulanmıştır. $\mathrm{Bu}$ testlerden elde edilen sonuçlar doğrultusunda hangi yöntemin uygulanacağına karar verilmiştir.

\section{F Testi}

F testi mevcut verilerin birimlere ve zamana göre farklılıklarının olup olmadığını tespit etmek amacıyla yapılan bir testtir. Daha net bir ifade ile bu test sabit etkiler yöntemine karşı havuzlanmış en küçük kareler yönteminin kullanılıp kullanılmayacağını tespit etmek için kullanılır. Olasılık değeri 0,05 den küçük ise en küçük kareler yöntemi tercih edilir eğer olasılık değeri 0,05 den büyük ise sabit etkiler modelinin tercih edilmesi uygun olur. Sabit etkiler modelinde de birey zaman etkisinin 
olmadığı kabul edilirken en küçük kareler yönteminde birey ve zaman etkisinin bulunduğu kabul edilir. Test sonuçlarına tablo: 7 de yer almaktadır; yapılan test sonucunda elde edilen sonuca göre olasılık değeri 0,05 den küçük olarak tespit edilmiştir. F olasılık değeri 0.05 den küçük olduğu için birim etkilerin sıfira eşit olduğu H0 hipotezi reddedilir. Buna göre modelin en küçük kareler yöntemi ile tahmin edilmeye uygun olmadığ $\breve{1}_{1}$ ifade edilir.

Tablo: 7 F Testi Sonuçları

\begin{tabular}{|c|c|c|}
\hline F Testi hipotezi & Ieğeri & Olastatistik değeri \\
\hline $\begin{array}{c}\mathrm{Ho}: \beta \mathrm{i}=\beta \text { (birey ve zaman } \\
\text { etkisi yoktur) }\end{array}$ & 25.46082 & $0.0000^{*}$ \\
\hline
\end{tabular}

*0.05 anlamlılık düzeyi

\section{Breusch-Pagan Langrange Multiplier(Çarpanı) Testi}

$\mathrm{Bu}$ test tesadüfi etkiler modeline karşı sabit etkiler modelinin uygun olup olmadığını tespit etmek amaciyla 1980 yılında Breusch-Pagan tarafindan geliştirilmiştir. Rassal etkiler modeli ile havuzlanmış model arasında tercih yapılmasına imkân sağlayan bu test birim etkiler varyansının sıfır olması durumunda rassal etkinin havuzlanmış model ile çözüleceğini ifade eder (Dizgil 2017: 265276). Test sonuçları ve hipotezi tablo:8 de yer almaktadır.

Tablo:8 Breusch-Pagan Lagrange Multiplier(Çarpanı) Testi

\begin{tabular}{|l|l|l|}
\hline LM Testi hipotezi & İstatistik değeri & Olasılık değeri \\
\hline Ho: $\operatorname{Var}(\mathrm{u})=0$ & 100.08959 & $0.0417^{*}$ \\
\hline
\end{tabular}

* Elde edilen sonuçlar \%5 anlamlı olup Ho reddedilmiştir.

LM test istatistiği ve olasılık değeri 1 serbestlik derecesinde $\mathrm{Ki}$ kare tablosu ile karşılaştırıldığında H0 hipotezi reddedilmiştir. Yani birim etkilerin varyansı sıfıra eşit değildir. Bu doğrultuda havuzlanmış modelin kullanılamayacağını ve panel etkisinin bulunduğunu söyleyebiliriz.

\section{Hausman Testi}

Panel veri analizinde birim ve zaman etkilerinin var olduğu tespit edilmişse o zaman bu etkilerin sabit mi yoksa tesadüfi mi olduğunu test etmek amaciyla bu test yapılır. Sabit ve tesadüfi modeller arasındaki en önemli farklardan biri de bağımsız değişkenlerle birimler arasındaki korelasyon ilişkisinin varlığıdır. Eğer bir korelasyon ilişkisi mevcut değilse tesadüfi etkiler modeli tercih edilmelidir (Dizgil 2017: 265-276). Bu teste ilişkin sonuçlar tablo:9 da yer almaktadır.

Tablo: 9 Hausman Testi Sonuçları

\begin{tabular}{|c|c|c|}
\hline Hausman Testi Hipotezi & Chi-Sq İstatistik & Olasılık değeri \\
\hline $\begin{array}{c}\text { Ho: Açıklayıcı değişkenler ile birimler } \\
\text { arasında korelasyon yoktur. }\end{array}$ & 21.840390 & $0.0013^{*}$ \\
\hline
\end{tabular}

* elde edilen sonuçlar \%5 düzeyinde anlamlı olup Ho reddedilmiştir. 
Olasılık değeri 0.05 in altında olduğundan dolayı modelin rassal etkiler yöntemi ile tahmin edilemeyeceği tespit edilmiştir. Bu sonuçlar doğrultusunda modelin sabit etkiler yöntemi ile tahmin edilmesi uygun bulunmuştur.

Otokorelasyon gözlemlenen değerler arasındaki benzerliğin zamansal gecikmenin bir fonksiyonu olarak ifade edilmesidir. Modelde Otokorelasyon sorununu tespit etmek için Durbin Watson test istatistik değerine bakılır. Bu değer 1.85 ile 2,15 arasında ise Otokorelasyon yoktur demektir. Durbin Watson değerine baktığımızda değerin 2.04 olduğunu görmekteyiz yani Otokorelasyon yoktur diyebiliriz.

\section{Panel Veri Analizi}

Çalışmanın bu kısmında ise $\mathrm{S}$ değerinin hesaplanmasında kullanılan değişkenlerin $\mathrm{S}$ değeri üzerindeki etkisini test etmek amacıyla bir çeşit çoklu regresyon yöntemi olan panel veri analizi yöntemi uygulanmıştır. Analizde bağımlı değişkenimiz $\mathrm{S}$ değeri bağımsız değişkenlerimiz ise $\mathrm{S}$ değerinin hesaplanmasında kullanılan finansal tablo birleşenleridir. Bunlar aktif toplamı, faiz vergi öncesi kar, kısa vadeli yabancı kaynaklar, aktif toplamı, dönen varlıklardan oluşmaktadır. $\mathrm{Bu}$ değişkenlerin logaritmalarının birincil farkları alınarak sabit etkiler yöntemine göre analiz edilmiştir. Değişkenlerin logaritmalarının alınmasının nedeni katsayıların daha anlamlı olmasını sağlamaktır. Logaritmalarının farklarının alınmasının sebebi ise değişkenlerin durağan olmasını sağlamaktır. Analiz sonuçları aşağıdaki tabloda yer almaktadır.

Tablo: 10 Panel Veri Analizi Sonuçları

\begin{tabular}{|c|c|c|c|c|}
\hline Değișkenler & Katsayılar & Std. Hata & T istatistik & Olasılık değ. \\
\hline Logkvykfark & -0.372941 & 0.272049 & -1.370859 & 0.1769 \\
\hline Logfvokfark & -0.109434 & 0.053921 & -2.029528 & $0.0481^{*}$ \\
\hline Logatfark & 0.256014 & 0.118398 & 2.162319 & $0.0357^{*}$ \\
\hline Logsatfark & 0.937856 & 0.317287 & 2.955863 & $0.0049^{*}$ \\
\hline Logdvfark & 0.023864 & 0.318998 & 0.074810 & 0.9407 \\
\hline C & -0.430039 & 0.070810 & -6.073128 & $0.0000^{*}$ \\
\hline R2 & 0.902049 & Düzeltilmiș R2 & 0.866621 & \\
\hline F istatistik & 25.46082 & Prob:0,00000 & & \\
\hline
\end{tabular}

*\% 0.05 düzeyinde anlamlılı̆̆ı ifade eder.

Analiz sonuçlarını incelediğimizde R2 değeri bize modelin açıklama gücünü vermektedir. Bu değer \%90 dır. Yani modelin açıklama gücü oldukça iyidir. Düzeltilmiş R2 ise bize modele eklenen bağımsız değişkenlerden dolayı yalancı şişkinliği önlemek için hesaplanmış değerdir. Bu da \%86 olarak hesaplanmıştır. Prob. olasılık değeri ise modelin bütüncül anlamlılığını göstermektedir. Bu değer 0.05 den küçük olduğu için modelimiz anlamlıdır. Yani bağımsız değişkenler bağımlı değişkeni \%89 açıklamaktadır. Değişkenlerin olasılık değerlerini incelediğimizde S değeri üzerinde etkili olan bağımsız değişkenlerin faiz ve vergi öncesi kar, aktif toplamı ve satışlar olduğunu görmekteyiz. Yani bu değişkenlerle s değeri arasında anlamlı bir ilişki tespit edilmiştir. Dönen varlıklar ile kısa vadeli yabancı kaynaklar ile S değeri arasında ise anlamlı bir ilişki tespit edilememiştir. Bu sonuçların ne 
anlam ifade ettiğini yorumlayacak olursak Springate modeline göre hesaplanan finansal başarısızlığın önceden tahminin kullanılan değişkenlerin $\mathrm{S}$ değeri üzerindeki etkisinin incelediği bu çalışmada satışlar, faiz ve vergi öncesi kar ile aktif toplamının S değerini etkilediğini söyleyebiliriz. Yani bu değişkenler yüksek değerlere sahip olması firmanın finansal başarısızlık ve iflas riskinin düşük olacağını ifade eder. Dönen varlıklar ile kısa vadeli yabancı kaynakların ise $\mathrm{S}$ değeri üzerinde bir etkisinin olmadığı tespit edilmiştir.

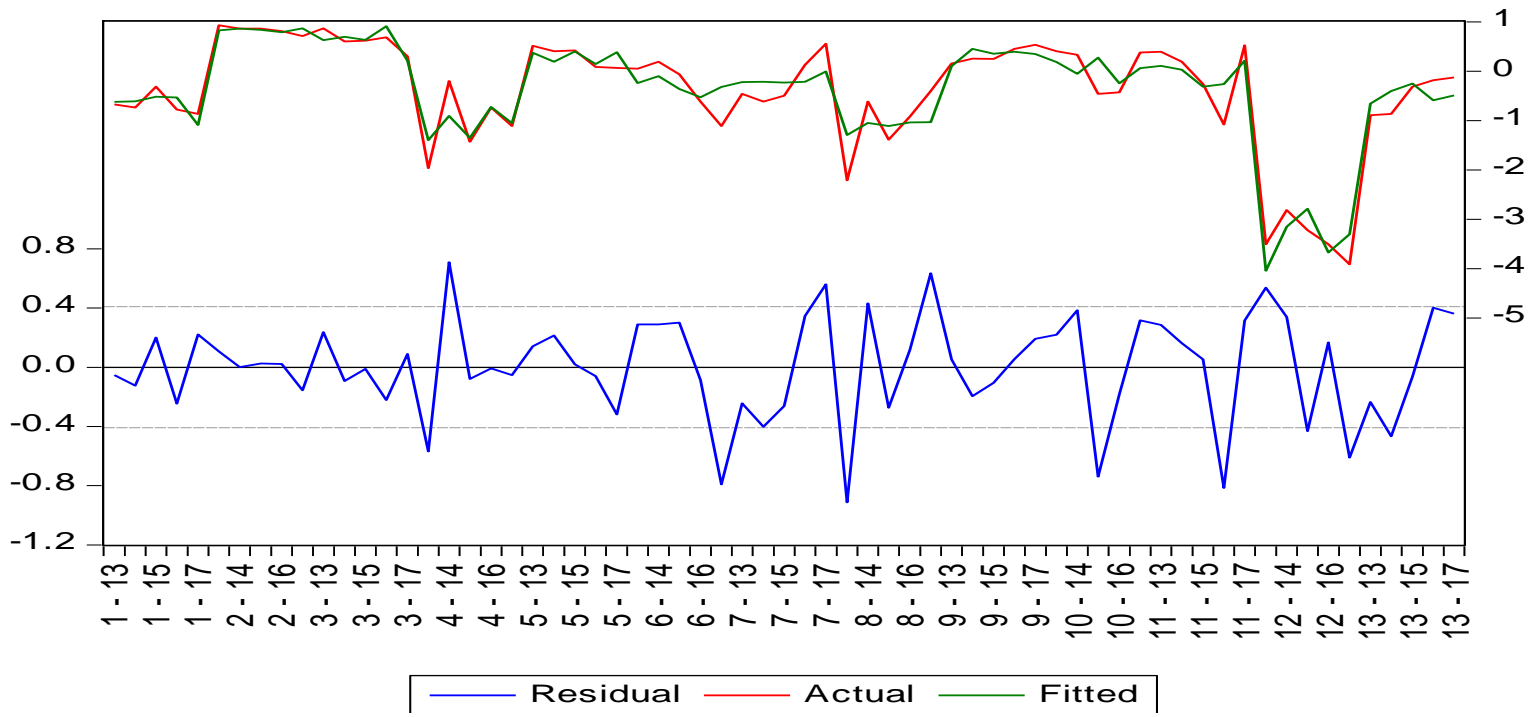

Şekil2. S bağımlı değişkeninin açıklanan, tahmin edilen, hata terimleri grafiği

$\mathrm{Bu}$ grafik ise bize bağımlı değişkenin açıklanan tahmin edilen ve hata terimlerin değerlerini göstermektedir. Grafikte mavi hata değerlerini, kırmızı ile gösterilen gerçek değeri, yeşil ile gösterilen ise tahmin edilen değerdir. Yeşil ile kırmızı birbirine ne kadar yakın olursa tahmin o derece iyidir, denilebilir. Bu grafikte de görüleceği üzere tahmin edilen bağımlı değişken değeri son derece iyidir seviyededir.

\section{SONUÇ}

Finansal başarısızlık hangi büyüklükte olursa olsun her sektörde faaliyet gösteren şirketlerin karşı karşıya kalabileceği olağan bir durumdur. Ülkedeki siyasi ve ekonomik istikrarsızlıklar, şirket yöneticilerinin başarısız kararları, piyasada yaşanan dalgalanmalar, grev, lokavt gibi olaylar şirketlerin finansal başarısızlık riskini artırmaktadır.

Bu çalışmada BİST Ticaret endeksinde yer alan 14 şirketin 2012-2017 yılları arası finansal tablo birleşenleri Springate finansal başarısızlık tahmin yöntemine göre incelenmiş ve Springate modeline göre hesaplanan S skoru ortalama 0,99'dur. Bu sonuca göre şirketlerin birçoğu finansal açıdan başarılıdır ve iflas riski düşüktür. Ancak Springate modeline göre iflas ve finansal başarısızlık riski bulunan şirketlerde analiz sonucunda tespit edilmiştir. Ancak bu şirketlere ilişkin iflas ve finansal başarısızlık öngörüsünün gerçekleşmediği görülmüştür. Ama iflas ya da finansal başarısızlık 
öngörüsünün gerçekleşmemesi şirketlerin risk atında olmadığı anlamına gelmemektedir. Çalışmanın bir sonraki kısmında ise Springate modeline göre belirlenen ve S skorunun hesaplanmasında kullanılan değişkenlerin S skoru üzerindeki etkisi çeşitli ekonometrik analizler yardımıyla incelenmiştir.

S Skoru ile finansal tablo birleşenleri arasındaki korelasyon ilişkisi incelendiğinde S Skoru ile satışlar ve faiz vergi öncesi kar arasında orta düzeyde korelasyon tespit edilirken dönen varlıklar ve S skoru arasında düşük düzeyde korelasyon ilişkisi tespit edilmiştir. Bunun anlamı S skoru ile faiz ve vergi öncesi kar ve satışlar arasında aynı yönde bir hareket olduğudur. Yani satışlar ve faiz vergi öncesi karlar arttığında veya azaldığında $S$ değeri de aynı yönde hareket etkilenmektedir.

S skoru ile finansal tablo birleşenleri arasındaki panel veri analizi sonucunda ise oluşturulan modelin açıklama gücü \%90 olarak tespit edilmiştir. Modelde bağımsız değişkenlerin bağımlı değişkeni \%89 oranında açıkladığı görülmektedir. S Skoru ile faiz vergi öncesi kar, satışlar ve aktif toplamı arasında ise pozitif anlamlı bir ilişki bulunmuştur. Bunu anlamı ise şirketlerin finansal başarılarında faiz vergi öncesi kar, satışlar ve aktif toplamının önemli olduğudur. Dönen varlıklar ve kısa vadeli yabancı kaynaklar ile $\mathrm{S}$ değeri arasında ise anlamlı bir ilişki tespit edilememiştir. Yani dönen varlıklar ve kısa vadeli kaynaklar S değerini açıklamada yetersiz kalmaktadır.

Analizler sonucunda Springate modelinin finansal performans değerlendirme açısından yararlı sonuçlar verdiğini söyleyebiliriz. Ortaya çıkan sonuçlara göre Springate modelinin iflası tahmin etmede kesin bir sonuç öngörmemektedir. Çünkü finansal başarı veya başarısızlık yalnızca şirketlerin finansal açıdan iyi bir performans göstermesine bağlı bir durum değildir. Bu kavramlar ayrıca şirket yönetiminin etkinliğine de bağlıdır. Finansal performansı iyi ancak şirket yönetimi başarısız ise sonuç olarak yine başarısızlık kaçınılmaz bir sondur. Buna ek olarak iflas öngörüsünün güvenilirlik düzeyi de yine şirket faaliyetlerinin objektif kriterlerle değerlendirilmesine bağlı olduğu unutulmamalıdır. Bu modelden elde edilen sonuçlar kreditörler, müşteriler, yatırımcılar için önem verilmesi gereken sonuçlardır. Çünkü halen birçok kredi derecelendirme kuruluşu şirketlerin kredibilitesini ölçmede bu modelden de faydalanmaktadır. 


\section{Kaynakça}

Aktaş, Ramazan, Mete Doğanay ve Birol Yıldız. «Mali Başarısızlığın Öngörülmesi; İstatistiki Yöntemler Ve Yapay Sinir Ağlarının Karşılaştırılması.» Ankara Üniversitesi SBF Dergisi (2003): 1-24.

Altaş, Dilek ve Selay Giray. «Mali Başarısızlığın Çok Değişkenli İstatistiksel Yöntemlerle Belirlenmesi.» Sosyal Blimler Dergisi (2005): 13-27.

Altman, E.I. «A Financial Rotios, Discriminant Analysis And The Prediction Of Corparate Bankrupcty.» The Journal Of Finance (1968): 589-609.

Aydın, Nurhan, Mehmet Başar ve Metin Çokun. Finansal Yönetim. Ankara: Detay Yayıncılık, 2010.

Beaver, Willam H. «Financial Rotios As Predictors Of Failure.» Journal Of Accounting Research (1966): 71102.

Büyükarıkan, Ulukan ve Birkan Büyükarıkan. «Blişim Sektöründe Faaliyet Gösteren Firmaların Finansal Bşarısızlık Tahmin Modelleri ile İncelenmesi.» Akademik Bakış Dergisi (2014): 160-172.

Dizgil, Eda. «Hisse senedi Fiyatını Etkileyen İşletme Düzeyi Faktörler: BİST Kobi Sanayi İşletmelerinde Yer Alan İşletmeler Üzerine Bir uygulama.» Javstudies (2017): 265-276.

Ege, İlhan, Esat Topaloğlu ve Aslı Erkol Yıkılmaz. «Fulmer Modeline Dayalı Finansal Başarısızlık İle Finansal Performans Arasındaki İlişki: İmalat Sanayi Üzerine Bir Uygulama.» Muhasebe Ve Finansman Dergisi (2017): 119-132.

Fulmer, Johns, et al. «A Bankruptcy Clasification Model For Small Firms.» Journal Of Commercial Bank Lending (1984): 25-37.

Kaти Aydinlatma Platformu. 2018.

Mazilla, Yusuf, Yaasmin Farzana Karim ve Fauziah Mohamed Yunus. «Financial Distress and Performance Relationship of Banks in Malaysia.» 5th International Conference On Business And Economic Research Proceeding. Malaysia, 2014.

Terzi, Serkan. «Finansal Rasyolar Yardımıyla finansal Başarısızlık Tahmini: Gıda Sektöründe Amprik Bir Araştırma.» Çukurova Üniversitesi İ̈BF Dergisi (2011): 1-18.

Türksoy, Adnan. «Konaklama İşletmelerinde Mali Başarısızlığa Yol Açan Etmenler.» Ege Akademik Bakış (2007): 99-115.

Uzun, Emin. «İşletmelerde Finansal Başarısızlığın Teorik Olarak İrdelenmesi.» Journal Mufad (2005): 1-11.

Yakıcı, Ayan, Tuba ve Nurdan Değirmenci. «Firma Finansal Bşarısızlık Öngörüsü İçin Bir Lojistik Regresyon Modeli.» UIIIID-IJEAS (2018): 77-88. 